\title{
NEWS AND INSIGHTS ON THE CONVERGENCE OF IFRS - U.S. GAAP
}

\author{
Ionela-Cristina Breahnă-Pravăţ \\ "Vasile Alecsandri" University of Bacău \\ crisspra@yahoo.com \\ Diana-Maria Diaconu ${ }^{1}$ \\ "Vasile Alecsandri" University of Bacău \\ diaconu.diana_maria@yahoo.com
}

\begin{abstract}
International accounting convergence is a highly complex process that began decades ago, emphasized globalization being the main factor that determined setters, professional bodies, investors to become aware of the importance of completing this process, namely the development and implementation of a common set of standards covering all areas of financial reporting. This objective was initially assumed by the International Accounting Standards Committee (IASC), now the International Accounting Standards Board (IASB).In this respect, at first it is noted the convergence of U.S. standards with the international ones, respectively the convergence of U.S. GAAP - IFRS standards, that, at least in theory, are not so different from each other, as we can say that, just as IFRS, U.S. GAAP were designed as a system of principles-based accounting. In reality, the U.S. standards system has proven to be more of a rules-based accounting system, unlike his international equivalent/counterpart. And the current state of convergence of the two sets of rules still reflects significant differences, plus the opposition of some entities to accept international standards.
\end{abstract}

\section{Keywords}

accounting; convergence; globalization; IFRS; U.S. GAAP.

\section{JEL Classification}

M41

\section{Introduction}

In order to develop a common language for the financial reporting, accounting has been at first phase submitted to a harmonization process, a process which later took the form of convergence.

Initial efforts in achieving accounting harmonization (a process that began after the Second World War) aimed to reduce differences in the accounting principles used in the most important capital markets in the world.

The most relevant evidence of harmonization process can be considered as the Accounting Directives issued by European Union through its main body: European Commission. They were taken more or less in law countries and influenced the accounting systems of countries outside the EU. Criticism of the harmonization process - the lack of a genuine conceptual basis, the close connection of accounting with taxation, the allowing of existence of a multitude of rules and accounting

\footnotetext{
${ }^{1}$ MSc student at "Vasile Alecsandri” University of Bacau
} 
practices - have made it to fail. Regional harmonization efforts have diminished the differences between accounting practices but could not eliminate them.

Therefore, giving up accounting harmonization in favor of convergence accounting (starting with the 90s), understood as a process of elaboration of rules, principles and unique concepts, meaning a single set of accounting standards, has proved to be effective, even if the process is not yet fully realized.

\section{IASB - International accounting convergence process' catalyst}

Efforts made on accounting convergence line (and previously on harmonization) would not have been possible without the existence of a body of international nature to approximate international accounting practices through a unique set of standards.

This responsibility was assumed by the International Accounting Standards Committee (IASC) established in 1973 and reorganized in 2001 as the International Accounting Standards Board (IASB).

As mentioned in the Constitution of the IFRS Foundation, one of the main objectives of the IASB is to achieve full convergence to a single set of global accounting standards of high quality, easy to understand and apply and promote these standards, in other words: do the converge of national accounting standards with international standards (IFRS Foundation Constitution 2010, http://www.ifrs.org/).

The concept of convergence highlights two major areas:

$\checkmark$ international convergence - the process in which the IASB and national bodies issuing accounting standards converge their financial reporting standards in a global set of accounting rules.

$\checkmark$ convergence of national standards - the adoption of international standards as national standards. For example, the Accounting Standards Board (ASB) in the UK has developed a strategy for the British regulatory convergence with international accounting standards.

Without minimizing the importance of convergence of national standards, we believe that the main challenge of the present is international convergence, relevant in this respect being the efforts of the IASB and the U.S. FASB accounting regulatory body (financial Accounting Standard Board), to bring to a common denominator international standards: IFRS (International Financial Reporting Standards), to the U.S.: U.S. GAAP (United States General Accepted Accounting Principles).

In light of the above, the very phrase "International convergence" is found in specific literature as being connected to convergence project initiated by the two bodies, given its importance.

\section{IFRS - US GAAP Convergence}

In the past decade, FASB and IASB have collaborated through joint projects in order to develop converged standards. FASB issued these standards as U.S. GAAP (Generally Accepted Accounting Principles), and the IASB has issued as IFRS (International Financial Reporting Standards). With time, it is expected that the two sets of quality standards evolve and become more similar, if not identical.

U.S. GAAP and IFRS, the two "pillars" of world regulatory accounting, competed certainly over time, for leadership in financial reporting (Tabără et al, 2010). However, collaboration has become necessary to both parties, because:

- IFRS influences U.S. companies as a result of increasing cross-border mergers and acquisitions of businesses, the increasing number of foreign investors, not least by 
policy to require branches of multinationals in the U.S. (and beyond) to prepare financial reports in accordance with IFRS.

- SUA U.S. still has one of the strongest and most developed capital markets in the world, attracting many companies. Moreover, continued delays in the decision to adopt IFRS by U.S. influences also decisions taken by other major powers such as: China, Japan and India that tend to delay the projects of their convergence to IFRS.

\subsection{Important steps in IFRS - US GAAP convergence}

United States has taken the first steps in accepting global accounting standards in 1988, when U.S. Securities and Exchange Commission (SEC) issued a statement that encouraged the development of international accounting standards.

For starters, the two bodies of normalization: IASB, FASB and SEC have agreed to work towards establishing a common set of standards, a process known as convergence.

In 2002 it signed the Norwalk Agreement, which formalized the beginning of cooperation between the two bodies: IASB and FASB. Cooperation supposed first to identify the main differences between the two systems by 2003 and reduce them by 2005.

Convergence projects were divided by this time in short-term projects and long-term projects, depending on the given priority.

FASB has also started an own research project on issues of international convergence. In 2006, the IASB and FASB have signed a Memorandum of Understanding, designating a joint committee to develop compatible accounting standards.

The target for 2008 was made up of the gap between the two reporting frameworks through short-term projects (joint or individual) aimed at the following areas: fair value, borrowing costs, impairment of assets, income, loans, government grants, research and development, joint ventures, future events, segment reporting .

Other joint projects, accomplished in a longer period of time, targeting the following 11 items: business combination, consolidation, guidance on measuring fair value, the distinction between debt and equity, performance reporting, employee benefits, revenue recognition, derecognition, financial instruments, intangible assets and leases. In 2007, SEC voted unanimously to allow private foreign companies that prepare financial statements in accordance with IFRS in the manner in which they were issued by the IASB, not to achieve their reconciliation to U.S. GAAP.

In 2008, the two councils have done the update convergence projects established by the Memorandum of Understanding, analyzing their status and indicating areas where the projects were completed.

In 2010 - the date on which occurred the second update of the Memorandum of Understanding - FASB and IASB issued a report quantifying convergence progress. In this report, the two councils establish, for the first time, a deadline for completion major projects convergence, namely 30 June 2011. The term was obviously, outdated. At this time, priority joint projects were related to: financial instruments, revenue recognition, leases, fair value measurement and presentation of other comprehensive income elements.

For IASB, projects scheduled for completion by the end of June 2011 include: strengthening, insurance and designing effective information requirements concerning derecognition of assets.

Also in 2010, Security and Exchange Commission in the U.S, started a work plan (The Work Plan) to examine the possibility of incorporating IFRS into the U.S. reporting system. 
In April 2011, "was issued the fourth progress report which concluded that the two councils have come close to completing the program set out in the Memorandum of Understanding.

At this time, the vast majority of short-term projects were completed, remaining only three projects (under long-term projects category), but of major importance: financial instruments, revenue recognition and lease accounting."

Meanwhile, the SEC has taken into account if and when there will be transition from U.S. GAAP to IFRS.

In November 2011, the SEC issued a 56-page report identifying the differences between U.S. GAAP and IFRS. The report is considered to be a limited one, since it does not refer to the differences between the two accounting referential in important areas such as: financial instruments, revenue recognition, leases, consolidation and fair value measurement, presentation of financial statements, financial instruments with characteristics of equity contracts insurance and asset derecognition (Work Plan for the Consideration of Incorporating International Financial Reporting Standards into the Financial Reporting System for U.S. Issuers - A Comparison of U.S. GAAP and IFRS, 2011, http://www.sec.gov/).

The report did not specify the impact of differences between U.S. GAAP and IFRS, however noted that U.S. GAAP, contains more detailed and specific requirements than IFRS "IFRS contain general principles for transactions in various industries, with specific application limited guidance”.

The report issued in April 2012 by the IASB leadership, emphasize that the three projects (set in $\mathrm{MI}$ ) remaining unfinished, were still under development, in bringing in addition the project on the subject of the insurance contracts, currently under review.

The final report issued by the SEC in July 2012 relative to the appropriateness of incorporating IFRS into the U.S. accounting system is not favorable, the SEC stating that the decision to achieve this purpose can not be taken while the major differences between the two sets of standards are maintained.

\subsection{GAAP Current status of IFRS - U.S. GAAP convergence process}

Year 2013 started with the creation of a new advisory forum under IFRS Foundation which oversees IASB, called Accounting Standards Advisory Forum. The purpose of its creation was to expand the possibilities of collaboration of the (International Convergence of Accounting Standards-Overview, 2013, www.fasb.org).

Currently, the members of this forum, bodies representing national and regional accounting normalization (in Africa, Asia, Oceania, Europe and America) are in number of 12, the FASB being among them.

While convergence future is still uncertain, the three projects pending in the Memorandum of Understanding - financial instruments, revenue recognition and leasing - together with the insurance contracts within follow their course.

Below we present work plans taken into consideration by the two standard setters: IASB and FASB containing timetables for completion of projects in stages. 
Table 1 The calendar of major IASB - FASB joint projects

\begin{tabular}{|c|c|c|c|}
\hline \multirow{2}{*}{$\begin{array}{l}\text { PROJECTS SET FORTH IN THE MEMORANDUM OF } \\
\text { UNDERSTANDING }\end{array}$} & 2013 & \multicolumn{2}{|c|}{2014} \\
\hline & $\mathrm{T} 4$ & S1 & S2 \\
\hline \multicolumn{4}{|l|}{ Financial accounting instruments } \\
\hline - Classification and assessment & & FD & \\
\hline - Depreciation & & FD & \\
\hline - Hedge accounting & $\mathrm{R}$ & $\mathrm{R}$ & $\mathrm{R}$ \\
\hline \multicolumn{4}{|l|}{ Leases } \\
\hline Revenue recognition & & FD & \\
\hline \multicolumn{4}{|l|}{ OTHER PROJECTS } \\
\hline Insurance & RT & $\mathrm{R}$ & \\
\hline \multicolumn{4}{|l|}{ Inactive joint projects } \\
\hline \multicolumn{4}{|c|}{$\begin{array}{c}\text { These projects were reconsidered as having a lower priority ranking. Their activation is not } \\
\text { expected in the near future }\end{array}$} \\
\hline \multicolumn{4}{|c|}{$\begin{array}{l}\text { 1) Accounting for financial instruments - rate liquidity and interest rate } \\
\text { 2) Conceptual frame (reporting entity; elements; evaluation; recognition) } \\
\text { 3) Earnings per share } \\
\text { 4) Emissions trading shares } \\
\text { 5) Financial instruments with characteristics of investment } \\
\text { 6) Presentation of financial information (income tax; investment companies) }\end{array}$} \\
\hline
\end{tabular}

Source: FASB - Project Roster \& Status, 2013, http://www.fasb.org/

Abbreviations:

FD: final document

R: re-deliberations

RT: round tables

\subsubsection{Financial instruments accountancy}

\section{a) Classification and assessment}

FASB proposal currently made on the classification and assessment of financial instruments differ substantially from those set forth in 2010, which require the submission of most financial instruments at fair value. The new proposal brings forward a mixed approach, respective the opportunity to measure assets and financial liabilities either at fair value or at amortized cost.

Financial assets will be assessed based on the appropriate estimated cash flows and type of business in which financial assets are managed.

Financial liabilities will be assessed according to how an entity is expected to be settled (generally, at amortized cost). Derivatives will not be subject to assessment mixed approach proposed by FASB, but will continue to be measured at fair value.

Regulatory submissions made by both bodies (FASB and IASB) will generate similar approaches in the assessment of investments held in bonds and financial liabilities. Significant differences remain, however, in the case of equity investments as IASB will allow assessment of the fair value of non-exchange traded other comprehensive income, rather than net income.

\section{b) Depreciation of financial instruments}

The model proposed by the FASB requires an entity to recognize a loss of credit based on the current estimation of the contractual cash flows not waited to be 
collected. This supposes recognition of aliquots of credit loses (basis for all financial instruments) since the first day, namely from day one, from the moment of recognition tools.

Unlike FASB, which proposes a single model for the evaluation of depreciation of financial instruments, the IASB has developed an assessment model that contains two approaches, referring to both losses and expected losses from lending. The proposed model requires recognition of expected losses to financial maturity assets whose credit risk has increased significantly from the initial recognition and the expected loss in the next 12 months for the other financial assets (KPMG, Course: IFRS 9 Financial Instruments, 2013, http://www.kpmg.com).

Although the model developed by the IASB is similar to its counterpart in that it allows the recognition of credit losses recognized since the time of the instruments, it is estimated that the losses recognized by using the model developed by the IASB is lower than the latter, because it does not make the recognition of losses expected to maturity of employment in certain minimum levels of value.

Even though the two models are different, their future trends have the same trajectory: the gradual removal from depreciation approach in terms of losses actually incurred. This approach has been criticized in the current financial crisis, considering that allowed entities to record credit losses in too small values to actual and relatively late times in relation to their production.

\section{c) Hedge accounting}

Although hedging models under both standards have similar principles, there are still some differences in the manner of their application. Some differences are arising from the rigor they have international standards compared with the U.S. and others, on the contrary, reflect the flexibility IFRS compared to U.S. GAAP.

Areas where IFRS are more restrictive than U.S. GAAP are referring to the nature, frequency and methods for assessing hedge effectiveness. For example, U.S. GAAP, provide a simple and quick method that allows an entity to assess that were no ineffective covering against risks and, therefore, to avoid conducting efficiency tests, as well as quantitative measurement of hedge ineffectiveness risks. In contrast, IFRS requires that efficiency against cover risks would be assessed in all cases, and any ineffectiveness is recorded in the profit and loss account.

\subsubsection{Leases}

Although the two bodies made significant adjustments to projects proposed in 2010, the major challenge in current practice is the virtual recognition in the balance sheet of assets and liabilities arising from leases. Agreeing on details, however, including the development of a model for the recognition of income from leasing operations, it is still a challenge (http://www.pwc.com/, U.S. GAAP and IFRS Convergence: What you need to know about the IASB and FASB's joint projects). Differences between the two types of standards are maintained on the classification of leases and gains recognition from lease-back transactions.

Currently, the two bodies have not reached consensus on an effective term of issuance of the final draft. In these circumstances, it is expected that the standard issue within the lease to produce later than 2014, the effective date is estimated to be around 2017.

\subsubsection{Revenue recognition}

According U.S. GAAP, revenue recognition is based on criteria based on fixed or determinable price, which means that in general, contingencies are not recognized as revenue, excepting the moment of their resolution (http://www.pwc.com/, IFRS and US GAAP: similarities and differences IFRS, October 2013), however, focuses on the 
likelihood that a transaction will generate future economic benefits to the entity and the possibility of measuring a manner reliability of these benefits, including any contingent revenue. These differences lead to unsynchronized moment income relating to the two types of standards.

In terms of progress towards convergence, the two accounting regulatory bodies are about to complete standard on revenue recognition. Latest updates within the projects: revenue recognition and discontinued operations are expected in the first quarter of 2014.

\subsubsection{Insurance Contracts}

Joint projects in the sphere of insurance contracts that are on the agenda of the two bodies agendas aimed at calculating and annuity and liabilities arising from insurance contracts by estimating future cash flows that are expected to be received, future payable compensation, and other charges laid in insurance.

The two bodies have failed to achieve convergence up to present in several major areas. For example, unlike the FASB, IASB continues to believe that the net contractual obligation that returns to insurer must include a specific degree of risk in terms of uncertainty when generating cash flow and amount.

Redeliberations on this project are expected in the course of 2014, the effective date of the completion of the standard is not yet established.

\section{References}

Ernst \& Young, SEC staff releases Final Report on IFRS, available on http://www.ey.com/Publication/vwLUAssets/Devels36_SEC_July2012/\$FILE/ Devels36_SEC_July2012.pdf.

FASB - International Convergence of Accounting Standards-Overview, available on http://www.fasb.org/jsp/FASB/Page/SectionPage\&cid=1176156245663.

FASB, International Convergence of Accounting Standards-A Brief History, available on http://www.fasb.org/cs/ContentServer?c=Page\&pagename=FASB\%2FPage \%2FSectionPage\&cid=1176156304264.

FASB, Project Roster \& Status, available on http://www.fasb.org/cs/ContentServer? c=Page\&pagename=FASB\%2FPage\%2FSectionPage\&cid=1218220137074.

Hitchins, J., Convergence limps on..., available on http://pwc.blogs.com/ifrs/2013/11/convergence-limps-on-in-2002-the-iasband-fasb-signed-up-to-the-goal-of-accounting-convergence-as-part-of-thenorwalk-agr.html.

Hoogervorst, H., Seidman, L. F., IASB-FASB Update Report to the FSB Plenary on Accounting Convergence, available on http://www.fasb.org/cs/ContentServer? site=FASB\&c=Document_C\&pagename=FASB\%2FDocument_C\%2FDocum entPage\&cid $=1176159985026$.

IFRS Foundation, IFRS Foundation Constitution, available on http://www.ifrs.org/The-organisation/IFRS-Advisory-

Council/Documents/ConstitutionDec2010.pdf.

IFRS Foundation, Work plan for IFRSs as at 26 November 2013, available on http://www.ifrs.org/Current-Projects/IASB-Projects/Pages/IASB-WorkPlan.aspx.

Meeting of the G20 Finance Ministers and Central Bank Governors 15-16 February 2013 Update by the IASB and FASB, available on http://www.financialstabilityboard.org/publications/r_130216b.pdf. 
PWC, IFRS and US GAAP: similarities and differences, available on http://www.pwc.com/us/en/issues/ifrs-reporting/publications/ifrs-and-us-gaapsimilarities-and-differences.jhtml.

PWC, US GAAP Convergence and IFRS: What you need to know about the IASB and FASB's joint projects, available on http://www.pwc.com/us/en/issues/ifrsreporting/publications/ifrs-convergence-joint-projects.jhtml.

Rotilă, A. (2011), Specific accounting regulations and practices, Alma Mater Publishing House, Bacău.

SEC, Work Plan for the Consideration of Incorporating International Financial Reporting Standards into the Financial Reporting System for U.S. Issuers. Final Staff Report available on http://www.sec.gov/spotlight/globala ccountingstandards/ifrs-work-plan-final-report.pdf.

SEC, Work Plan for the Consideration of Incorporating International Financial Reporting Standards into the Financial Reporting System for U.S. Issuers - A Comparison of U.S. GAAP and IFRS, A Securities and Exchange Commission Staff Paper, 16 November, 2011, available on http://www.sec.gov/spotlight/ globalaccountingstandards/ifrs-work-plan-paper-111611-gaap.pdf.

Tabără, N., Horomnea. E., Mircea. M. C. (2010), International accounting, Second Edition, Tipo Moldova Publishing House, Iaşi. 